\title{
Pelatihan Penguatan Partisipasi Politik dalam Mengawal Kebijakan Publik
}

\author{
Sunarto $^{1}$, Sulton $^{2}$, Ardhana Januar Mahardhani ${ }^{3}$ \\ ${ }^{1,2,3}$ Universitas Muhammadiyah Ponorogo \\ email : sunarto@umpo.ac.id', sulton@umpo.ac.id²,ardhana@umpo.ac.id ${ }^{3}$
}

\begin{abstract}
The form in the implementation of politics in students can be shown through the level of political participation in various activities, such as during the implementation of general elections both legislative and executive, the election of chairmen in the community or student organization, as well as special attention to all policies issued by the government. The purpose of this activity is to provide students with an understanding of various problems that exist in society so that they have high social sensitivity. This community service activity is carried out by the University of Muhammadiyah Ponorogo in the form of training with activities used are lectures, peer discussions, case studies, and role-playing. The material provided in the training is about carrying out the movement, starting the movement, preparing the movement, strengthening the movement, and controlling and following up on the movement. To find out the results of students' understanding of the material, pre-test and post-test were given with the results increasing from $40 \%$ to $90 \%$. The conclusion of this training is the establishment of a Citizenship Community to strengthen the strategic position of students as agents of change and social control to always oversee public policies issued by the regions.
\end{abstract}

Keywords: political participation students, public policy.

\begin{abstract}
Abstrak
Wujud dalam pelaksanaan politik pada mahasiswa dapat ditunjukkan melalui bagaimana tingkat partisipasi politik dalam berbagai aktivitas, seperti pada saat pelaksanaan pemilihan umum baik legislatif dan eksekutif, pemilihan ketua pada komunitas atau organisasi kemahasiswaan, serta adanya perhatian khusus pada segala kebijakan yang dikeluarkan oleh pemerintah. Tujuan dalam kegiatan ini adalah memberikan pemahaman kepada mahasiswa tentang berbagai persoalan yang ada di masyarakat agar mempunyai kepekaan sosial yang tinggi. Kegiatan pengabdian kepada masyarakat ini dilaksanakan oleh Universitas Muhammadiyah Ponorogo dalam bentuk pelatihan dengan aktivitas yang digunakan adalah ceramah, diskusi teman sejawat, studi kasus, dan bermain peran. Materi yang diberikan dalam pelatihan adalah tentang melaksanakan gerakan, memulai gerakan, mempersiapkan gerakan, memperkuat gerakan, dan mengawal serta menindaklanjuti gerakan. Untuk mengetahui hasil pemahaman mahasiswa terhadap materi diberikan pre-test dan post-test dengan hasil meningkat dari $40 \%$ naik menjadi $90 \%$. Kesimpulan dari diselenggarakannya pelatihan ini adalah dibentuknya Komunitas Kewargaan dalam rangka memperkuat posisi strategis mahasiswa sebagai agent of change dan social control untuk selalu mengawal kebijakan publik yang dikeluarkan oleh daerah.
\end{abstract}

Kata Kunci: partisipasi politik, mahasiswa, kebijakan publik

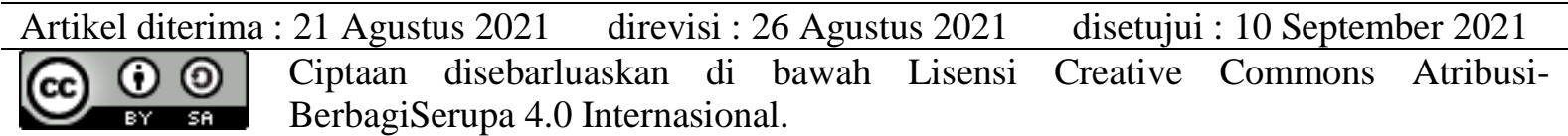




\section{Pendahuluan}

Partisipasi dalam berpolitik pada saat menjadi mahasiswa merupakan sebuah ketrampilan yang harus dimiliki untuk digunakan pada saat mahasiswa tersebut lulus dan berbaur di masyarakat. Dalam arti luas berpolitik mempunyai pengertian menjalankan politik, sedangkan politik berarti melaksanakan interaksi antar manusia dengan mengandalkan kekuasaan yang dimiliki untuk selanjutnya ditransfer kepada orang lain dan dimanfaatkan dalam kegiatan bersama (Arifin, 2018). Hal ini sesuai dengan asal kata politik yang dalam bahasa Yunani yaitu 'polis' atau kota yang berstatus negara kota (city state) (Hidayat, 2009).

Wujud dalam pelaksanaan politik pada mahasiswa dapat ditunjukkan melalui bagaimana tingkat partisipasi politik dalam berbagai aktivitas, seperti pada saat pelaksanaan pemilihan umum baik legislatif dan eksekutif, pemilihan ketua pada komunitas atau organisasi kemahasiswaan, serta adanya perhatian khusus pada segala kebijakan yang dikeluarkan oleh pemerintah.

Pada saat ini mahasiswa memiliki tingkat partisipasi politik yang sangat rendah (Agus et al., 2020; Trisna \& Fatmariza, 2019), bahkan pada mahasiswa di Universitas Muhammadiyah Ponorogo (Rahayu, 2020). Mahasiswa sebagai agent of change belum bisa untuk menggunakan kemampuan pikirnya untuk mencoba mendalami lebih jauh tentang pelaksanaan politik yang merupakan bagian terpenting dari tata laksana kehidupan. Sebagai social control, mahasiswa juga belum mampu untuk menunjukkan wujud nyata dalam memberikan perlindungan dan pendampingan terhadap masyarakat yang terkena dampak dari keluarnya kebijakan publik. Kebijakan publik tidak terlepas dari berbagai kepentingan banyak pihak, oleh karenanya dalam kebijakan publik juga tidak terlepas dari adanya aktivitas politik (Mahardhani, 2020).

Kebijakan publik secara sederhana dapat didefinisikan sebagai sebuah keputusan yang dibuat oleh pemerintah untuk merealisasikan tujuan yang telah direncanakan dalam rangka menuju perubahan yang telah diharapkan (Hasbi et al., 2021; Mahardhani, 2018). Mahasiswa diharapkan mempunyai daya nalar yang kritis dan selalu berfikir sistemik terhadap kebijakan publik ini, oleh karenanya mereka selalu diberikan latihan-latihan yang terkait dengan studi kasus dalam rangka memberikan pemahaman kepada mahasiswa tentang berbagai persoalan yang ada di masyarakat serta mempunyai kepekaan sosial yang tinggi.

\section{Metode Pelaksanaan}

Dalam kegiatan pengabdian kepada masyarakat ini metode yang digunakan adalah pelatihan. Secara umum model pelatihan lahir dengan tujuan untuk meningkatkan pengetahuan dan ketrampilan seseorang yang dilaksanakan pada lembaga tertentu serta berkaitan dengan kebutuhan belajar, proses belajar, assessment, sasaran, dan adanya tantangan lainnya.

Pelatihan dalam kegiatan ini dilaksanakan selama 2 (dua) hari yaitu pada tanggal 19 sd 20 Juni 2021 di Universitas Muhammadiyah Ponorogo dengan jumlah peserta adalah 55 orang mahasiswa yang berasal dari program studi Pendidikan Pancasila dan Kewarganegaraan, Fakultas Keguruan dan Ilmu Pendidikan dengan pemateri dalam pelatihan adalah: (1) Sunarto, S.Pd. (Pimpinan DPRD Kabupaten Ponorogo), (2) Ayub Dwi Anggoro, Ph.D, (3) Dr. Sulton, M.Si., (4) Drs. Sunarto, M.Si., dan (5) Dr. Ardhana Januar Mahardhani, M.KP. seperti pada gambar 1 di bawah.

Aktivitas pelatihan yang dilakukan terdiri dari tiga bagian yaitu pre-test, materi, dan post-test. Evaluasi pelatihan dilakukan secara terpisah dalam rangkaian kegiatan oleh panitia penyelenggara. Pemaparan materi menggunakan metode ceramah, diskusi teman sejawat, studi kasus, dan bermain peran. Hal ini dimaksudkan untuk memberikan pemahaman yang lebih kuat kepada para peserta pelatihan. Sedangkan luaran dalam penelitian ini adalah terben- 
tuknya sebuah wadah bagi mahasiswa untuk proses pembelajaran dengan membentuk Komunitas Kewargaan yang salah satu tugasnya adalah memberikan advokasi kepada masyarakat yang terdampak dari adanya kebijakan daerah serta mengawal kebijakan yang telah dikeluarkan oleh daerah.

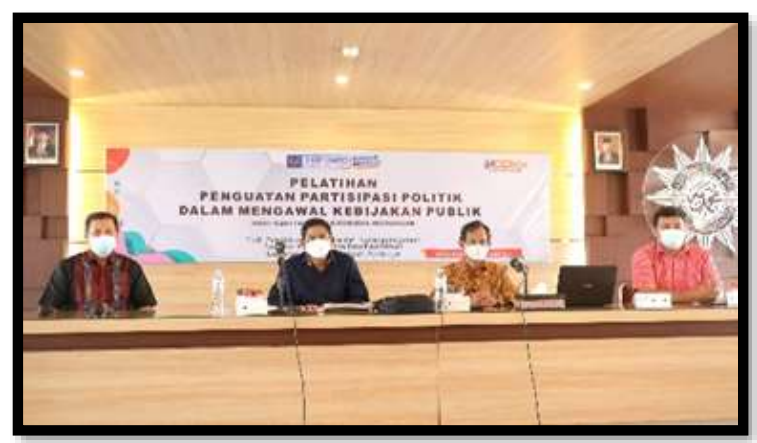

Gambar 1. Pemateri dalam Pelatihan

\section{Hasil dan Pembahasan}

Dalam pelaksanaannya terdapat perluasan materi yang diberikan kepada para peserta, tidak hanya tentang literasi politik tetapi pada partisipasi politik mahasiswa. Indonesia mempunyai permasalahan dalam hal literasi secara umum dan juga dalam hal literasi politik. Penyelenggaran Pemilu perlu terus memperbaharui program-program literasi politik bagi masyarakat, terutama ditujukan bagi anak-anak muda umur 17 sampai 35 tahun. Literasi politik secara umum merupakan upaya untuk menjadikan setiap warga negara untuk berpartisipasi politik secara kritis dengan membekali diri kemampuan dan kapabilitas politik. Maka, ketika warga negara berpartisipasi politik, baik partisipasi politik formal seperti pemilu dan pilkada maupun partisipasi politik dalam bentuk lainnya, semestinya hal itu dilakukan dengan kapabilitas politik yang memadai.

Pelaksanaan pelatihan penguatan partisipasi politik dalam rangka mengawal kebijakan publik di daerah khususnya pada kabupaten Ponorogo ini sangat penting untuk dilakukan, selain sebagai salah bentuk penguatan peran mahasiswa sebagai agen perubahan juga menguatkan kedudukan mahasiswa dalam rangka membentuk jati- diri mahasiswa sebagai aktivitis sehingga bisa memberikan masukan yang baik untuk pemerintah daerah sebagai pembuat kebijakan. Berikut adalah materi penguatan yang diberikan dalam pelatihan:

\section{Tabel 1. Materi Pelatihan}

\begin{tabular}{|c|c|c|}
\hline No & Materi & Uraian \\
\hline 1 & Orientasi & $\begin{array}{l}\text { - Apa dan mengapa } \\
\text { advokasi } \\
\text { - Memahami kebi- } \\
\text { jakan publik }\end{array}$ \\
\hline 2 & $\begin{array}{l}\text { Melaksanakan } \\
\text { gerakan }\end{array}$ & $\begin{array}{l}\text { - Menggalang se- } \\
\text { kutu dan pendu- } \\
\text { kung } \\
\text { - Mempengaruhi } \\
\text { pembuat kebija- } \\
\text { kan }\end{array}$ \\
\hline 3 & $\begin{array}{l}\text { Memulai } \\
\text { gerakan }\end{array}$ & $\begin{array}{l}\text { - Merancang stra- } \\
\text { tegi dan sasaran } \\
\text { - Mengolah data } \\
\text { dan mengemas } \\
\text { informasi }\end{array}$ \\
\hline 4 & $\begin{array}{l}\text { Mempersiapkan } \\
\text { gerakan }\end{array}$ & $\begin{array}{l}\text { - Membentuk ling- } \\
\text { karan inti } \\
\text { - Memilih isu stra- } \\
\text { tergis }\end{array}$ \\
\hline 5 & $\begin{array}{l}\text { Memperkuat } \\
\text { gerakan }\end{array}$ & $\begin{array}{l}\text { - Membentuk pen- } \\
\text { dapat umum (opi- } \\
\text { ni) } \\
\text { - Membangun ba- } \\
\text { sis gerakan }\end{array}$ \\
\hline 6 & $\begin{array}{l}\text { Mengawal dan } \\
\text { menindaklanjuti } \\
\text { gerakan }\end{array}$ & $\begin{array}{l}\text { - Memantau dan } \\
\text { menilai gerakan }\end{array}$ \\
\hline
\end{tabular}

Enam materi diberikan secara bersambung sehingga diantara keenam materi tersebut merupakan suatu kesatuan. Materi pertama disampaikan oleh Drs. Sunarto, M.Si. yaitu orientasi, dalam orientasi ini dimaksudkan para mahasiswa mengetahui tentang gambaran umum dari advokasi, seberapa penting advokasi tersebut dilakukan oleh mahasiswa dan apa dampak yang muncul jika mahasiswa tersebut mengawal kebijakan publik di daerah.

Dalam pelaksanannya pada materi orientasi peserta pelatihan diberikan waktu untuk mengerjakan pre-test dalam rangka mengetahui tingkat pemahaman awal dari maksud pelatihan. Pre-test yang diberikan 
kepada mahasiswa adalah pertanyaan-pertanyaan dalam rangka mengetahui pemahaman mahasiswa tentang kebijakan dan advokasi kebijakan, diantaranya: 1. Apakah saudara mengetahui definisi kebijakan publik?; 2. Apakah saudara mengetahui tentang partisipasi politik dalam kebijakan publik?; 3. Apakah saudara mengetahui aktor dalam kebijakan publik?; 4. Apakah saudara mengetahui definisi tentang advokasi kebijakan publik?; 5. Apakah saudara mengetahui tentang bagan arus advokasi?.

Hasil dari pre-test menunjukkan bahwa $40 \%$ mahasiswa yang mengetahui tentang kebijakan publik, partisipasi politik dalam kebijakan publik, aktor kebijakan, dan advokasi kebijakan publik. Dari pretest yang telah diadakan semua mahasiswa belum mengetahui tentang bagan arus advokasi.

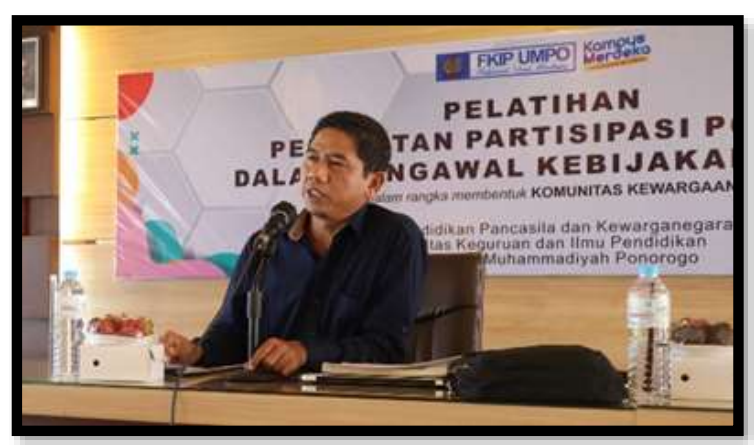

Gambar 2. Penyampaian materi dari Ketua DPRD Kabupaten Ponorogo

Pada materi kedua yaitu melakukan gerakan diisi oleh Sunarto, S.Pd. yang merupakan ketua DPRD Kabupaten Ponorogo seperti gambar 2 di atas, beliau memberikan materi tentang menggalang sekutu dan pendukung serta mempengaruhi pembuat kebijakan. Hal ini dimaksudkan agar materi yang diberikan aplikatif dan sesuai dengan keadaan yang ada di kabupaten Ponorogo. Keluasan jejaring sangat dibutuhkan dalam kegiatan ini oleh karena itu dengan pemilihan pembicara kompeten dibidangnya akan memberikan gambaran nyata tentang pemerintahan dan kebijakan yang saat ini sedang terjadi di kabupaten Ponorogo.
Materi selanjutnya adalah memulai gerakan disampaikan oleh Dr. Sulton, M.Si. yang berisi merancang sasaran dan strategi serta bagaimana mengolah data serta mengemas informasi. Pada pelaksanaannya mahasiswa diberikan contoh kasus yang saat ini sedang terjadi di kabupaten Ponorogo, sebagai bentuk penyelesaian kasus mereka akan mensimulasikan dengan merancang strategi apa yang harus dilakukan dalam rangka mengatasi permasalahan tersebut termasuk juga mencari data lanjutan yang dibutuhkan untuk menjawab pertanyaan atas kasus dengan mengemas informasi yang tepat.

Kemajuan zaman seperti saat ini juga memerlukan panduan khusus dalam proses pengemasan informasi terutama yang berasal dari media sosial seperti facebok, twitter, youtube, instagram, dan masih banyak lainnya, hal ini dikarenakan informasi dari media sosial jika tidak dilakukan pengecekan kebenaran malah menjadikan hal tersebut hoax dan permasalahan tersebut akan kembali ke pemberi infomasi (Hartanto et al., 2020).

Saling keterkaitan materi yang ada dalam pelatihan ini menjadikan materi selanjutnya juga langsung dilakukan dengan kasus yang sama, yaitu mahasiswa diberikan gambaran tentang bagaimana membentuk lingkaran inti advokasi dan memilih isu yang akan diangkat dalam kasus tersebut. Hal ini menjadi inti dari materi mempersiapkan gerakan.

Mempersiapkan gerakan merupakan hal yang penting dalam sebuah kegiatan pendampingan masyarakat yang terdampak kebijakan pemerintah. Dalam pelatihan ini materi mempersiapkan gerakan diberikan oleh Dr. Ardhana Januar Mahardhani, M.KP., dalam materi tersebut mahasiswa diberikan penjelasan tentang pihak mana saja yang terlibat dalam sebuah perumusan kebijakan. Oleh karenanya dalam mempersiapkan gerakan mereka juga dikenalkan pada organisasi kemasyarakatan, non government organization, lembaga swadaya masyarakat, serta komu- 
nitas yang berpengaruh di kabupaten Ponorogo.

Selanjutnya pada materi memperkuat gerakan yang diberikan oleh Ayub Dwi Anggoro, Ph.D peserta pelatihan diberikan pemahaman tentang membentuk pendapat umum (opini) serta bagaimana membangun basis gerakan, ini menjadi bagian yang sangat penting karena kekuatan komunikasi dalam berbagai gerakan masyarakat menjadi basis utama, sehingga ketrampilan komunikasi menjadi suatu kebutuhan yang harus dimiliki oleh mahasiswa seperti bagaimana pemilihan kata yang tepat, penyesuaian nada bicara dan intonasi, serta menyesuaikan diri dengan lawan bicara.

Pada materi terakhir yaitu mengawal dan menindaklanjuti gerakan para peserta pelatihan mencoba untuk mensimulasikan penyelesaian kasus yang ada di Kabupaten Ponorogo terkait dengan impelementasi kebijakan publik. Pemateri dalam pertemuan materi terakhir ini adalah semua tim. Peserta pelatihan melaksanakan presentasi atas hasil yang telah didiskusikan bersama teman satu kelompoknya. Dalam pelaksanaannya kelompok lain mempunyai kesempatan untuk menanggapi atau memberikan masukan atas jawaban dari kelompok yang sedang presentasi, sehingga dalam kegiatan pelatihan ini terjalin hubungan dua arah.

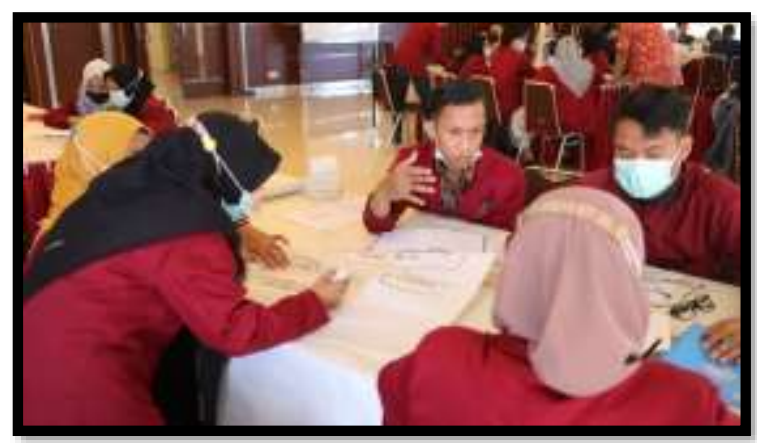

Gambar 3. Diskusi peserta dalam pelatihan

Pada akhir kegiatan pelatihan dibentuk komunitas dengan nama Komunitas Kewargaan dengan anggota mahasiswa yang telah lulus dalam pelatihan ini. Komunitas Kewargaan dimaksudkan seba- gai organisasi otonom mahasiswa yang mempunyai minat dalam kegiatan pemerintahan, mengawal kebijakan publik yang telah dikeluarkan oleh pemerintah daerah, serta memberikan advokasi kepada masyarakat atas turunnya kebijakan tersebut. Sehingga dari terbentuknya komunitas tersebut menjadikan mahasiswa lebih kuat dalam partisipasi politik.

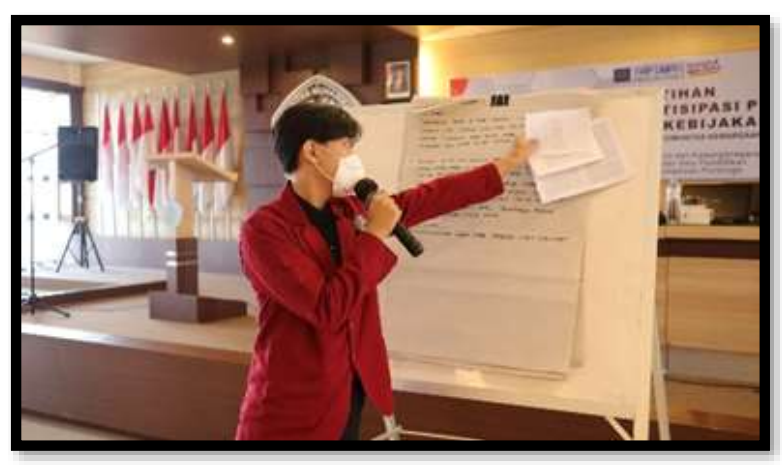

Gambar 4. Presentasi kasus dalam pelatihan

Post-test juga dilakukan dalam rangka mengetahui tingkat pemahaman peserta pelatihan dan evaluasi atas kegiatan yang telah dilakukan selama dua hari. Post-test dilakukan dengan pertanyaan yang sama pada saat pre-test, dari hasil post-test diketahui bahwa terjadi peningkatkan pemahaman dari pelaksanakan pre-test, yaitu sebesar 90\% mahasiswa telah memahami tentang kebijakan publik, partisipasi politik dalam kebijakan publik, aktor kebijakan, dan advokasi kebijakan publik. Selain itu dalam rangka untuk mengetahui kepuasan mahasiswa dalam mengikuti kegiatan pelatihan juga diadakan evaluasi kegiatan dalam rangka memberikan masukan kepada panitia penyelenggara.

\section{Simpulan}

\section{Penutup}

Penguatan partisipasi politik pada mahasiswa dapat dilakukan dengan aktivitas pelatihan. Diselenggarakannya pelatihan penguatan partisipasi politik oleh Universitas Muhammadiyah Ponorogo ini tentu akan mengembalikan peran mahasiswa, melalui Komunitas Kewargaan juga diharapkan dapat mengawal kebijakan 
publik yang di daerah sehingga dapat mengembalikan posisi strategis mahasiswa sebagai agent of change dan social control.

\section{Saran}

Tentunya kegiatan pelatihan ini merupakan bentuk awal dari memperkuat peran mahasiswa dalam organisasi kemasyarakatan. Pelatihan ini menjadi embrio dalam kegiatan pelatihan selanjutnya setelah terbentuknya Komunitas Kewargaan di Program Studi Pendidikan Pancasila dan Kewarganegaraan, Universitas Muhammadiyah Ponorogo.

\section{Ucapan Terima Kasih}

Ucapan terimakasih juga tim pengabdi sampaikan kepada Lembaga Penelitian dan Pengabdian Masyarakat (LPPM) Universitas Muhammadiyah Ponorogo yang telah memberikan anggaran untuk pelaksanaan kegiatan pelatihan penguatan partisipasi politik dalam mengawal kebijakan publik.

\section{Daftar Pustaka}

Agus, A. A., Badaruddin, S., Muhkam, M. F., \& Umalia, A. D. (2020). Pengaruh Pengetahuan Politik Terhadap Tingkat Partisipasi Politik Mahasiswa Pada Pemilihan Presiden Tahun 2019-2024 (Studi Pada Mahasiswa Jurusan PPKn FIS UNM). SUPREMASI: Jurnal Pemikiran, Penelitian Ilmu-Ilmu Sosial, Hukum Dan Pengajarannya, 15(2), 112-120. https://doi.org/10.26858/supremasi.v1 $5 \mathrm{i} 2.19679$

Arifin, A. (2018). Pengaruh Pendidikan Politik Terhadap Partisipasi Politik Mahasiswa Prodi PPKn FKIP Universitas Muhammadiyah Ponorogo Pada Pelaksanaan Pemilihan Umum Kepala Daerah Provinsi Jawa Timur Tahun 2018. Universitas Muhammadiyah Ponorogo.

Hartanto, R. V. P., Triyanto, T., Yuliandari, E., \& Ariana, Y. (2020). Civic Literasi Bijak Dalam Bermedia Sosial Bagi Ibu-Ibu PKK Kecamatan
Banjarsari Kota Surakarta. Cendekia : Jurnal Pengabdian Masyarakat, 2(1), 16-23.

https://doi.org/10.32503/CENDEKIA .V2I1.677

Hasbi, I., Hartoto, Maharani, D. S. L. E. D., \& Mahardhani, A. J. (2021). KEBIJAKAN PUBLIK. Bandung: Widina Bhakti Persada.

Hidayat, I. (2009). Teori-Teori Politik. Malang: Penerbit Setara Press.

Mahardhani, A. J. (2018). Advokasi Kebijakan Publik. Ponorogo: Calina Media.

Mahardhani, A. J. (2020). Persepsi Mahasiswa Terhadap Mata Kuliah Kebijakan Publik. Citizenship Jurnal Pancasila Dan Kewarganegaraan, $8(2)$, 68-75. https://doi.org/10.25273/CITIZENSH IP.V8I2.6606

Rahayu, W. A. (2020). Demokrasi di Kampus: Partisipasi Politik Dalam Pemilihan Umum Raya Badan Eksekutif Mahasiswa Universitas Muhammadiyah Ponorogo Tahun 2019. Universitas Muhammadiyah Ponorogo.

Trisna, V., \& Fatmariza, F. (2019). Faktor - Faktor Penyebab Tingginya Partisipasi Politik Mahasiswa pada Pemilu Badan eksekutif Mahasiswa Periode 2018-2019. Journal of Civic Education, 2(3), 197-205. https://doi.org/10.24036/jce.v2i3.150 